\title{
A suitability assessment using an instrumented impact test of the use of selected structural steel grades on the basis of their changes in response to exposure to fire
}

\author{
Paulina Zajdel \\ paulinazajdel22@gmail.com | (1) http://orcid.org/0000-0002-1940-0106 \\ Faculty of Civil Engineering, Cracow University of Technology
}

Scientific Editor: Andrzej Winnicki, Cracow University of Technology Technical Editor: Aleksandra Urzędowska, Cracow University of Technology Press Language Editor: Tim Churcher, Big Picture Typesetting: Małgorzata Murat-Drożyńska, Cracow University of Technology Press

Received: March 23, 2021

Accepted: April 21, 2021

Copyright: ( 2021 Zajdel. This is an open access article distributed under the terms of the Creative Commons Attribution License, which permits unrestricted use, distribution, and reproduction in any medium, provided the original author and source are credited.

Data Availability Statement: All relevant data are within the paper and its Supporting Information files.

Competing interests: The authors have declared that no competing interests exist.

Citation: Zajdel, P. (2021). A suitability assessment using an instrumented impact test of the use of selected structural steel grades on the basis of their changes in response to exposure to fire. Technical Transactions, e2021007. https://doi.org/ 10.37705/TechTrans/e2021007

\begin{abstract}
In this article, changes occurring in structural steel after exposure to fire are described and discussed. The steel structure before and after fire determines its susceptibility to brittle cracking. The individual phases of cracking are described and interpreted on the basis of a load-displacement graph, directly obtained from the Charpy impact test. The relationship between the intensity of individual fracture energies and the type and appearance of the sample fractures are demonstrated. The program of planned Charpy impact tests and expected hazards after the exposure to fire of selected steel grades are presented. Standard simplified load-displacement graphs are assigned to the steel transition curve. The course of various cracking mechanisms occurring in the case of brittle fractures and plastic fractures are discussed. The aim of this article is to evaluate the possibility of the assessment of structural steel after a fire based on results obtained during the Charpy impact test.
\end{abstract}

Keywords: instrumented impact Charpy test, brittle fracture, plastic fracture, mixed fracture 


\section{Introduction}

The instrumented impact test enables the unambiguous assessment of the plastic properties of steel, in particular the stress associated with the cracking of microvoids and the effectiveness of crack arrest (Chaouadi and Fabry, 2002). This method can be effectively used in tests for assessing the properties of structural steel after a fire due to its sufficiently accurate results and the relatively low cost of the test. The graphs and their characteristic points obtained from the impact test allow the identification of a distinction between individual phases of cracking, and thus the determination of the material's ability to arrest cracks (Stankiewicz at al., 2012). Being a chaotic thermal treatment, a fire usually increases the brittleness of the material with a simultaneous deterioration of its plastic properties (Trilleros, Mato, and Huertas, 2012). The extent of these changes and their impact on the safety of the structure made of this material can be assessed by testing the microstructure and by using the impact test (Maślak, 2012).

The changes observed in the steel microstructure after exposure to fire and subsequent cooling of the material to room temperature are generally permanent changes, and thus they determine the possibility of the further use of the structural element made of this material. The threats resulting from these types of changes depend on the group of steels under consideration, as well as the temperature affecting them, the speed of their heating and the method of cooling. The rest of the article presents adverse phenomena occurring in various steels during a fire, and also indicates the possibility of assessing their consequences after the fire, based on the analysis of the results obtained from the instrumented Charpy impact test.

\section{Changes of steel properties after a chaotic thermal treatment}

Changes occurring in structural steels during classic heat treatments, such as normalisation, hardening and tempering, as well as various annealing variants, serve to improve the functional properties of steel, and their course is planned and controlled. The fire is characterised by the chaotic effect of high temperature on the analysed material, so when it is initiated, phase transitions in steel occur in an uncontrolled manner. The effect of adverse structural changes is generally an increase of material hardness and a deterioration of its plasticity, which may result in an increased susceptibility to brittle cracking, and thus the risk of a sudden and catastrophic destruction of the steel structure.

The basic question of assessing the structure of structural steels after a fire is determining whether the material temperature exceeded the initial temperature of the phase transitions during heating. However, even when this temperature is not exceeded, the structure of the steel exposed to fire could noticeably change. Phenomena that affect its mechanical properties occur at a temperature of around $450 \mathrm{oC}$; these are associated with the onset of diffusion of alloy elements. One such phenomenon is ferrite grain growth, which causes the disappearance of the banded structure of rolled materials.

The phenomenon of a grain growth under the influence of exposure to high temperature has been described in many works (for example in (Trilleros, Mato, and Huertas, 2012)) and confirmed in experimental studies. It has been shown (Maciejewski at al., 2012) that up to $600 \mathrm{oC}$, the size of ferrite grains does not change significantly; however, above $7000 \mathrm{c}$, the average growth of these grains is very significant and reaches a value over $50 \%$. In addition, at this heating temperature, the disappearance of perlite grains and the onset of the spheroidisation of cementite in perlite were also visible.

During a fire, the steel structure is exposed to direct flames and possibly air heated to a high temperature. This causes oxidation on the outer surface of steel elements. An oxide layer called a scale is formed. After the fire, the 
surface of the cooled-down steel is covered with iron oxide. The colour of the residue enables the estimation of the maximum temperature of the fire. Heating to a temperature below $250 \mathrm{oC}$ results in a yellow residue colour. Steel heated to such a temperature does not significantly lose its properties. A blue residue colour indicates that the steel has been heated to a temperature of from $250 \mathrm{oC}$ to 400 oC. In a typical structural steel (e.g. S355) tertiary cementite can separate, and in low-alloy steels - carbides and nitrides of alloying elements at the grain boundaries, which causes the phenomenon of ageing. The result is deterioration of plastic properties (Maślak and Żwirski, 2017).

Heating of structural steel to a temperature of $7000 \mathrm{C}$ to $800 \mathrm{oC}$ (i.e. above the re-crystallization temperature) results in the formation of a thicker scale which mainly consists of $\mathrm{FeO}, \mathrm{Fe}_{2} \mathrm{O}_{3}$ and $\mathrm{Fe}_{3} \mathrm{O}_{4}$. In this case, the steel is covered with a brittle and porous layer of residue, and in the case of long exposure to such high temperature, there is also the phenomenon of the melting and oxidation of the grain boundaries in the near-surface layer. After prolonged exposure to such high temperature, elements made of typical structural steel, as a rule, can no longer be used after a fire. In this type of steel, there is often a partial transformation of perlite into austenite. Some grains undergo a transformation typical of normalisation. When heating steel, fine-grained austenite is formed from perlite; however, during its slow cooling, the perlitic-ferritic structure is produced again, but with smaller grains than those observed before the transformation. When not participating in the phase change, grains do not change their original size and shape. However, when cooling is intense (fire fighting with water), focal points of perlite grains of considerable thickness are formed. In S355 steel, even when heated to a temperature slightly above the A1 phase transition threshold level, an undesirable Widmanstätten pattern may arise. This structure, if created, causes a significant increase of the steel hardness but, at the same time, a significant deterioration of its plasticity. Therefore, the material is very susceptible to brittleness in this case and is thus vulnerable to catastrophic cracking. It should be added that a higher content of carbon and manganese increases the susceptibility of steel to this adverse phenomenon (Maślak and Żwirski, 2017).

The increase in the cooling rate may result in the formation of a partial bainitic structure, observed as grains of carbon-supersaturated ferrite, with cementite precipitated between them. The type of bainite (upper or lower bainite) depends on the temperature and the cooling rate. Lower bainite is a particularly unfavourable steel structure. It shows considerable hardness and a very high tendency to brittle cracking.

At high cooling rates, martensitic transformation may occur. It is a completely diffusionless transformation, during which strong structural stresses arise. Martensite is more susceptible to brittle cracking than bainite. Bainitic and martensitic transformations also cause the complete disappearance of the banded structure (Maślak and Żwirski, 2017).

\section{Models of simulated fire influence}

Samples made of SN490C steel have been tested (Peng, Chi and Cheng, 2016) simulating fire conditions firstly by heating them in a laboratory oven to various temperature levels, from $6000 \mathrm{C}$ to $1000 \mathrm{oC}$ in steps of $100 \mathrm{oC}$, and then by maintaining properly heated samples at a given temperature for 60 minutes. Finally, the heated samples were cooled in two alternative ways - by water cooling and by open-air cooling. In the study, the temperature associated with perlitic transformation was exceeded in only a few cases. However, in general, it was not achieved at all in other situations. The steel microstructure observed after the experiment depended not only on the heating temperature but also on the method of sample cooling. With the slow free open-air cooling of the material for any of the previously assumed heating temperature values, neither bainitic 
transformation nor martensitic transformation occurred. However, with rapid cooling in water, after preheating the steel to a temperature above the perlitic transformation (i.e. to levels successively $800 \circ \mathrm{C}, 900 \mathrm{oC}$ and $1000 \mathrm{oC}$ ), the more the share of both the bainitic structure and the martensitic structure in the total volume of the tested material increased, the higher maintained temperature of the sample was. The dependence of the measured impact strength on the heating temperature and on the cooling method of the tested samples, observed in the reported study, is shown on Figure 1. As can be seen, following intense cooling with water, the clearer the visible deterioration of the identified impact strength, the higher the temperature acting on the steel was. Cooling in water also resulted in a significant decrease in the relative elongation of the cooled samples measured after the test. However, it should be noted that with this method of cooling, the progressive reduction in impact strength essentially disappeared at the steel temperature corresponding to its perlitic transformation, and it in turn, resulted in the tested impact toughness being determined as more or less constant. With the free open-air cooling of the samples, the reduction in impact strength with the increase in sample heating temperature turned out to be significantly smaller in relation to the corresponding reduction identified at the same temperature and associated with water cooling. Moreover, at a sufficiently high steel temperature, even a significant increase in the tested impact strength was observed, probably caused by local hardening of the material. In the author's assessment, this may mean that under these conditions, the plastic properties of the steel under study have not yet significantly deteriorated in this area. It seems that such seemingly rather unusual behaviour of the cooled down material can be explained by the very slow and basically constant pace of cooling down, definitely different from the rapid cooling simulated by placing hot samples in a water bath. It is also worth emphasising that a sufficiently high level of impact strength is maintained in the case of samples being cooled down in the open air and heated in a simulated fire to a temperature of at least $800 \mathrm{oC}$.

The intensive cooling of heated steel with cold water may also result in the formation of a mesh of internal microcracks, which increase the risk of sudden destruction during possible further use of an element made of such a treated material after a fire. However, it should be particularly emphasised that each steel group will behave differently in such circumstances, specific to its type and chemical composition. In the reported study (Peng, Chi and Cheng, 2016), the KV impact energy values obtained for SN490C steel turned out to be so high that in the absence of other types of restrictions, they guaranteed the continued safe use of its structural elements after a fire.

The speed of heating and cooling of steel after a fire affects the initiation of perlitic, bainitic and martensitic transformations, as well as the ability to deform grains of its microstructure. As the temperature of the material subjected to external loading increases, its susceptibility to the elongation of individual ferritic matrix grains also increases. In

Fig. 1. Impact toughness of SN490C steel as a function of heating temperature and cooling method [according to (Peng, Chi and Cheng, 2016)]

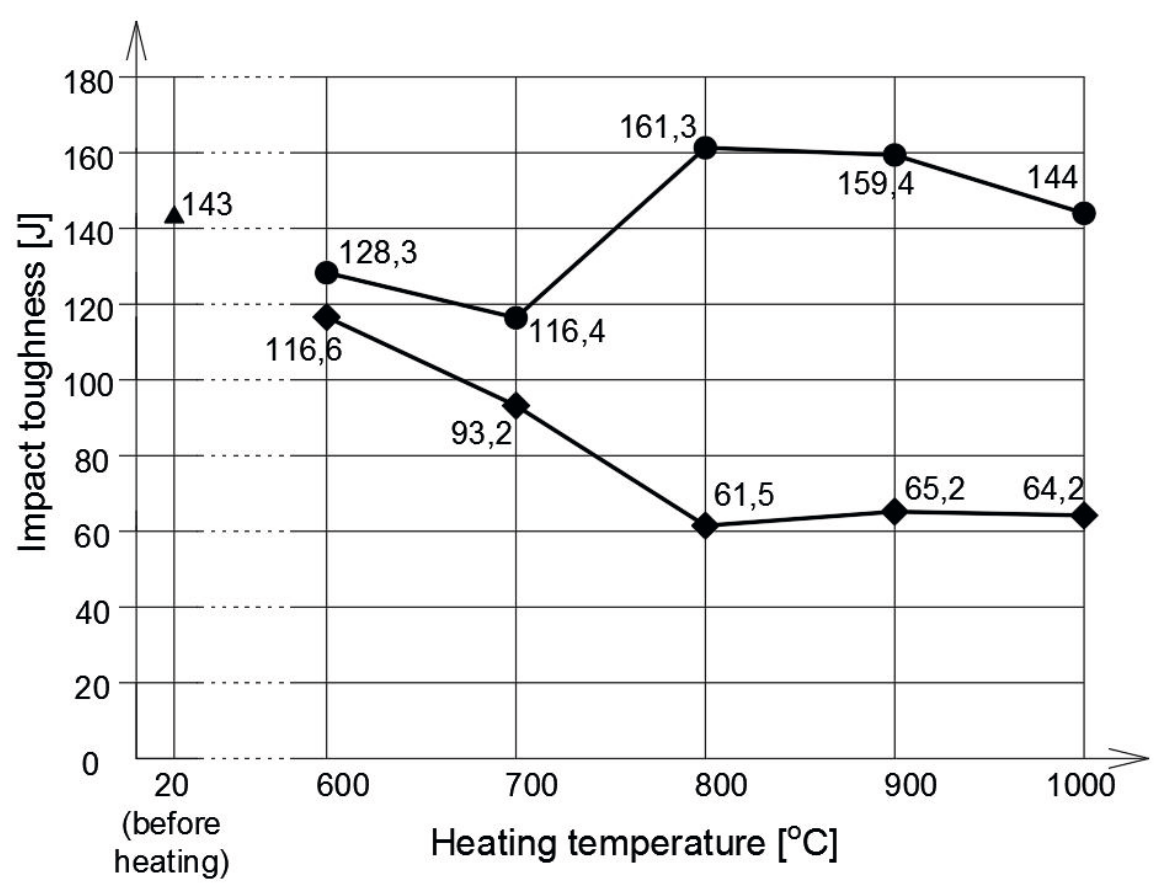

cooling in air cooling in water bath 
experimental studies described in (Bednarek and Kamocka, 2006), it was shown that an increase in the heating rate of steel causes a decrease in the effective and orderly elongating ability of grains, and as a consequence, an increase in susceptibility to brittle cracking observed after cooling down. With sufficiently slow heating, ferrite grains subjected to directed loading are somewhat linearly elongated in a natural way due to the direction of the impact of the load. However, if the steel temperature rises significantly faster, the ferrite grains arranged in the steel structure in a chaotic manner will not manage to coordinate the directions of their deformations with each other. Therefore, the chaotic deformation of individual grains is intensified by their multidirectional growth. The more individual grains grow, the higher temperature is. In such degenerated material, structural defects and voids are easily and randomly created, which weakens it further. It should be emphasised that the disordered grain deformations arising when heating steel generally does not disappear after it has been cooled down, even very slowly. Therefore, if during a fire the material is not able to gradually order the deformation of the expanding ferrite grains, it generates thermal stresses as material imperfections with a pattern that is difficult to identify and it is thus very unfavourable with regard to the possibility of its future use.

The author intends this article to serve as an introduction to her own series of impact tests of selected grades of structural steel, related to their conditions after simulated exposure to fire. In planned tests, Charpy $\mathrm{V}$ notched impact samples of standard shape and standard dimensions, made from selected steel grades, will first be heated in a laboratory furnace to a specified temperature and will then be kept at this temperature for a sufficiently long time before being cooled down to room temperature. The first group of samples will be cooled down in a water bath to simulate the fire-fighting action. The samples of the second group, for comparative purposes, will be cooled down in the open air. This scenario corresponds to a natural and slow extinguishing of the fire, such as would occur if the fire simply burnt itself out. After cooling, samples of both groups will be subjected to an instrumented Charpy impact test. Two scenarios of simulated fire impact have been selected for a comparative analysis. In the first of these scenarios, the samples will be heated to a temperature of $600 \mathrm{oC}$, while in the second, they will be heated to a temperature of $8000 \mathrm{C}$. The temperature of $800^{\circ} \mathrm{C}$ is above the temperature of the perlitic transformation onset, so when the steel is heated to this temperature,

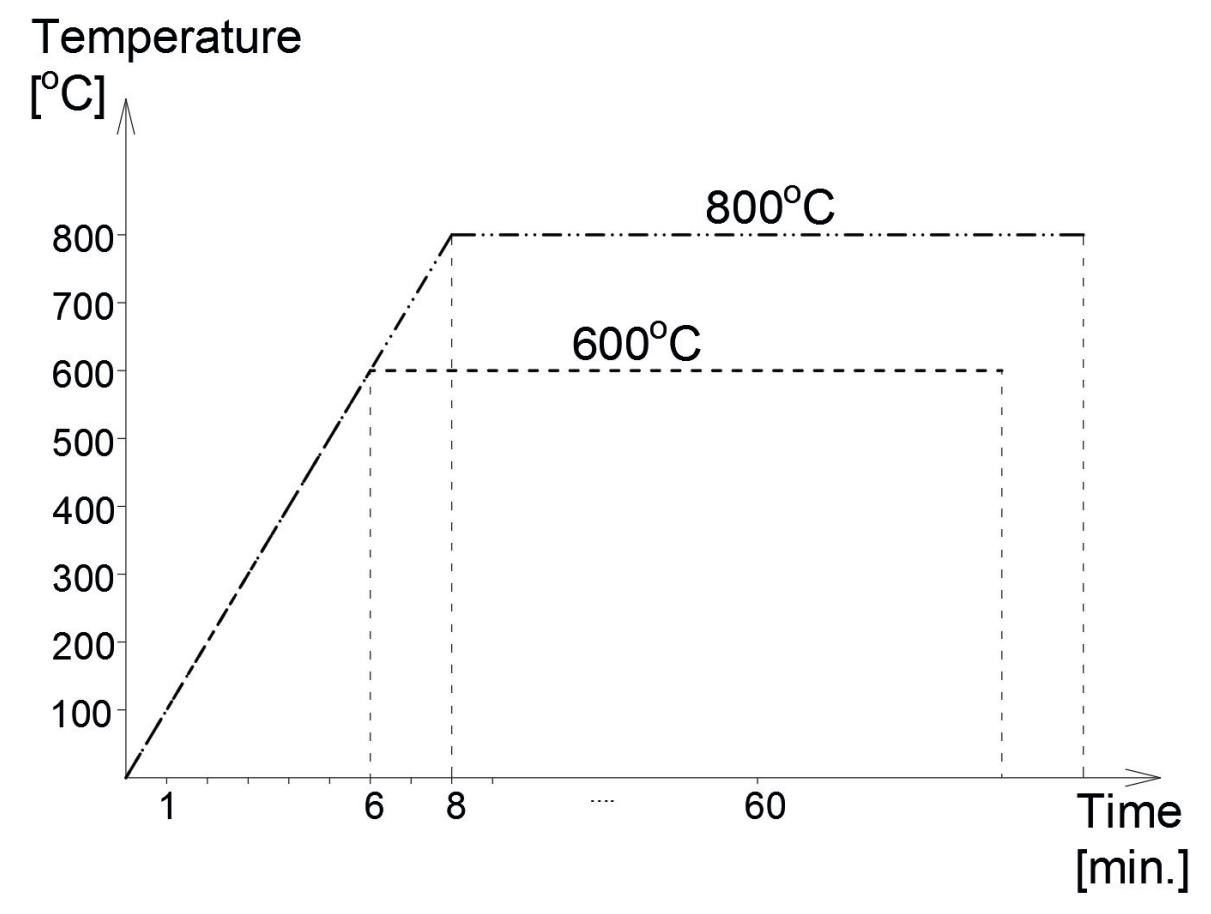

phase transitions may occur, in particular perlitic transformation and partly bainitic transformation and/ or martensitic transformation. The temperature of $600 \mathrm{oC}$, on the other hand, is below the temperature of the onset of perlitic transformation, but at the same time, above the carbon diffusion start temperature identified for S355 steel. The heating rate in both tested scenarios was set at 100 oC per minute, which fully corresponds to the recommendations formulated in (Maciejewski at al., 2012). In each of the considered cases, the maximum sample temperature will be kept constant for one hour and after that time, the cooling phase will begin. The scenarios for the development of the simulated fire impact discussed above are detailed in Figure 2.

Fig. 2. Fire impact scenarios simulated in research [own study] 
A series of samples comprised of four steel grades will be tested. Each of these grades was considered by the author to be representative of a given group of structural steels with specific behaviour expected for each group after going through heating and cooling episodes in a simulated fire. The loaddisplacement relationship is expected to be different in each tested steel group and is identified during impact tests conducted independently for the cooleddown samples, and thus, as a consequence, a qualitatively different conclusion is obtained about the suitability of a given steel for its further use. The steels selected for the study differ in their basic application and specific internal structure. They are as follows:

- S355 steel - a commonly used low-alloy steel with increased manganese content, used for the production of profiles and plates. It has a dominant ferritic structure with banded perlite. It is an easily weldable steel with increased resistance to atmospheric corrosion and is not very sensitive to short-term thermal effects at temperatures up to $350 \mathrm{oC}$.

- $1 \mathrm{H} 13$ steel - used for external cladding and chimney constructions. It contains an increased amount of chromium that guarantees a passive surface layer under atmospheric conditions. This steel is resistant to atmospheric corrosion.

- 1H18N9T steel - used for the construction of industrial equipment, tanks and for decorative reasons for railings, balustrades, etc. It is an austenitic steel in which carbon is stabilised by the addition of titanium. The chemical composition makes it possible to create a surface layer resistant to strong oxidising acids and their salts. This steel used in temperatures up to $600 \mathrm{oC}$ due to the danger of sigma phase separation in the temperature range of $6500 \mathrm{C}-850 \mathrm{oC}$.

- Duplex SDSS steel (1.4462) - used for making tanks, pipelines and bridge structures in environments containing chloride. The microstructure of this steel consists of high-temperature delta ferrite containing chromium and molybdenum, as well as austenite in proportions of around $50 \% / 50 \%$. It has a high yield limit with good ductility. It has an increased resistance to intergranular corrosion and, in the case of steel grades containing molybdenum, increased resistance to electrochemical corrosion in chlorides. It is used in the temperature range up to $3000 \mathrm{C}$ due to the occurrence of brittleness at $4750 \mathrm{oC}$.

After exposure to high temperature, different hazards and a different degree of material degradation may arise in each of the tested steels. Expected phenomena related to individual steel grades are as follows:

- S355 steel - austenitic transformation (above 727oC) and significant grain growth. Due to the lack of a protective surface layer, steel undergoes surface corrosion during high temperature oxidation.

- 1 H13 steel - the surface layer based on high chromium content in steel causes an increased resistance to atmospheric corrosion at high temperature. However, the lack of other alloying additions results in lower chemical resistance than is found in austenitic steels. At high temperatures, chromium carbides saturated with chromium and carbon, which cause a significant increase in hardness and lower ductility, may become separated from ferrite. Thus, when the chromium content of the solid solution decreases, the protective properties of the surface layer deteriorate.

- 1H18N9T steel - fast separation of the sigma phase with long-term strength or slow cooling in the temperature range of $650 \mathrm{oC}$ to $850 \mathrm{oC}$ results in a significant drop of the impact strength to values even below 10J. The surface layer has resistance to oxidation, so corrosion is limited.

- Duplex SDSS steel (1.4462) - the phenomenon of brittleness occurring at $4750 \mathrm{C}$ causes a significant increase in susceptibility to cracking. The initiation of the phenomenon of brittleness occurs above $300^{\circ} \mathrm{C}$ as a result of releasing non-coherent, brittle phases reducing the steel plasticity. 


\section{Methodology for interpreting research results}

The instrumented Charpy impact test enables an accurate verification of steel in terms of its potential fragility. The graphs of the load, energy and displacement relationships as a time function, as well as the load and energy relationships as a displacement function will be obtained from the study. The planned tests will enable the obtaining of load-displacement graphs and will be matched to graphs A - F according to the standard (PN-EN ISO 14556:2015). Analysis of crack initiation and propagation energy (corresponding fields under the loaddisplacement graph) enables the crack behaviour to be determined, specifically, whether it is an arresting or disastrous crack. The instrumented Charpy test software automatically determines the characteristic points of the force value on the resulting graphs, which will enable the development of a thorough analysis of the individual phases of the cracking process in the sample. On the basis of the received graphs and their analyses, conclusions will be drawn regarding the general nature of the fracture and the course of individual phases of the cracking process. During impact testing, steel samples may crack with a completely plastic, completely brittle, or mixed fracture. The load-displacement graph for the most common case (a mixed fracture) is presented in Fig. 3. In the elasticplastic range, the first observed extremum is the $F_{m}$ value - up to this point, the sample cracking initiation is stable. After exceeding the $F_{m}$ load, a stable fracture growth occurs, i.e. cracking with plastic deformation. The $F_{\text {iu }}$ point is the load initiating the unstable fracture growth. After reaching the $F_{a}$ load, the unstable fracture is inhibited and the sample goes into the phase of plastic breaking. The $F_{g y}$ value is also an important point on the graph. This is the general plasticity load corresponding to the point where the plastically deformed zone has reached the opposite cross-sectional area of the sample below the notch. The plastic fracture front is formed between the $F_{\text {gy }}$ loads and the $F_{m}$ maximum load. The initial fracture growth is stable until unstable growth occurs, followed by propagation arrest in the inhibiting phase (Chaouadi and Fabry, 2002). The load-displacement graph correlates very well with the crack appearance. The areas under the graph marked in Fig. 3 show the energy values of individual components of the fracture. The described course of the load-displacement curve corresponds to a type $\mathrm{E}$ from the standard curves. Only unstable, brittle crack growth occurs for an extreme type A. A completely plastic fracture (type F) does not contain the area of unstable fracture - all phases of the fracture

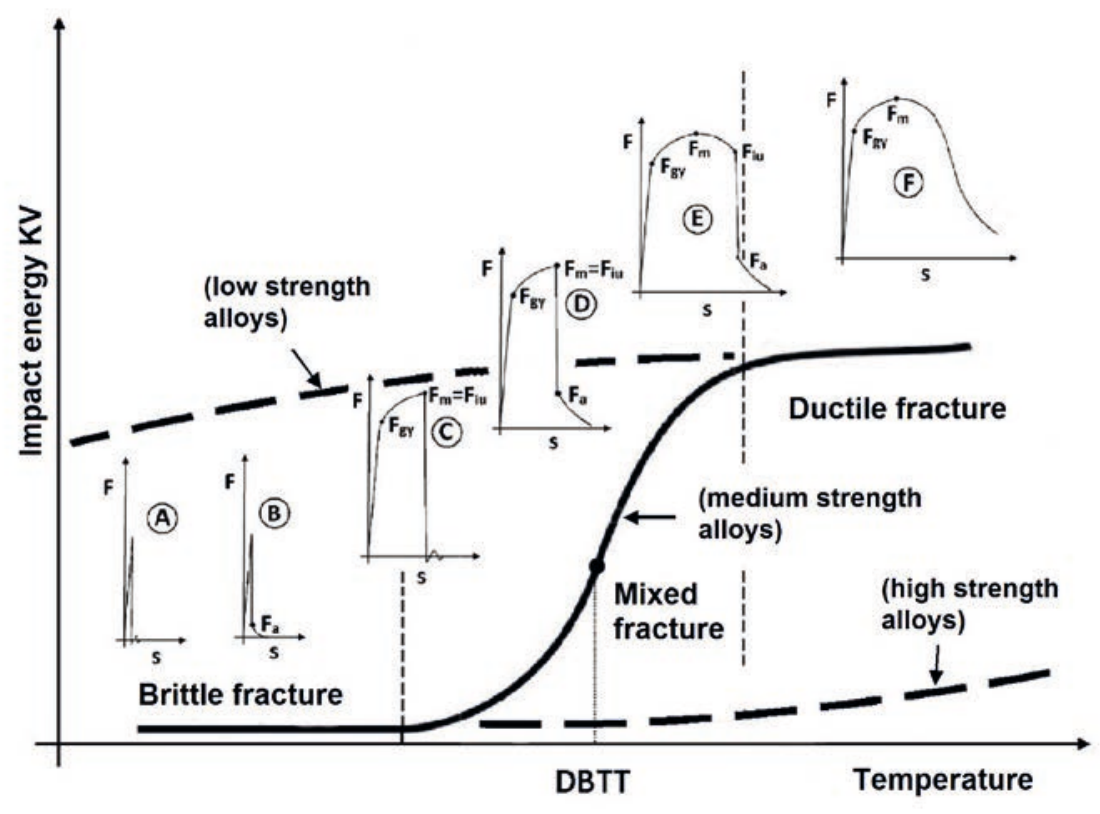
are stable and the fracture stops automatically. The greater the area under the graph to the right of the $\mathrm{F}_{\mathrm{a}}$ load, the greater the ability to inhibit cracking and the greater the area of ductile breaking of the sample visible in the fracture.

The most desirable graphs in impact tests are the $E$ and $F$ graphs from the standard curves, with the highest crack propagation inhibiting energy. Steel that behaves this way during impact testing is a material that will not be immediately destroyed, and therefore a structure

Fig. 3. Theoretical form of the Floaddisplacement graph of the point of application of the s load in the instrumented impact test for a mixed fracture sample. Characteristic values of load and energy absorbed by the sample are marked [own study according to (Lin at al., 2017), (Server W.L.,2002)] 
made of such elements is safe for people working on cleaning up the area after a fire. The A, B and C type load-displacement graphs show a complete lack of crack arresting area. In such cases, destruction occurs suddenly and may have uncontrollable effects. Steel of this nature is not suitable for further operation in post-fire conditions and also poses a threat to people who clean up after the fire.

The individual regions of the mixed fracture are marked in Fig. 4. The surface of each area corresponds with regard to its percentage to each energy area marked on the load-displacement graph. Due to the impact of the hammerhead, a strong stress concentration occurs under the notch root that initiates a crack. The crack width gradually increases towards the impact point of the hammerhead. On the side surfaces of the sample, the number of freedom of deformation degrees is greater than in the centre, and therefore ductile fracture is possible in these areas. In the central part of the sample, unstable brittle cracking occurs. Completely brittle fracture (A type from standard (PN-EN ISO 14556:2015)) is only characterised by the occurrence of an unstable crack growth area throughout the entire cross section of the sample. However, in a completely plastic fracture ( $F$ type of the standard (PN-EN ISO 14556:2015)), the central area of unstable crack growth disappears, and the area of stable crack growth and the area of breaking of the sample increase.

In Fig. 6, the load-displacement standard graphs obtained from Charpy instrumented impact test were assigned to areas of the steel transition curve. The impact value of $\mathrm{KV}_{\text {min }}=27 \mathrm{~J}$ corresponds to a conventional steel transition temperature (DBTT). Below this value, the steels show a dominant brittle nature of the fracture. Steels with these graph types are not desirable for use in construction. The use of steel in such conditions is not safe due to the possibility of uncontrolled sudden destruction. Steels with pronounced arresting cracks have the character of a load-displacement graph located on the right side of the DBTT temperature in Fig. 6. By assigning individual types of standard graphs to the transition curve, it is easy to assess which graph shapes characterise steels permanently useful for construction, and which steels are always dangerous.

Brittle and ductile fractures also show different mechanisms of cracking. Inclusions such as carbides, oxides, borides, nitrides, silicates are incoherent with the matrix and constitute a crystallographic void. These inclusions cause a mechanism of cracking that occurs on the lower section of the transition curve - it is the dominance of the brittle fracture. Manganese sulphides and microvoids in the structure cause damage on the upper section of the curve - it is the dominance of the ductile fracture. The appearance of the mechanism of cracking corresponding to the lower plateau in the graph in Fig. 6 may be a consequence of unwanted changes occurring as a result of fire, for example, after separation of the sigma phase, austenitic steel becomes very brittle (KV <10J). Knowledge of mechanisms of

Fig. 4. Mixed fracture areas [own study according to (Lin at al., 2017), (Sorochak at al., 2017), (Tanguy at al., 2005)]

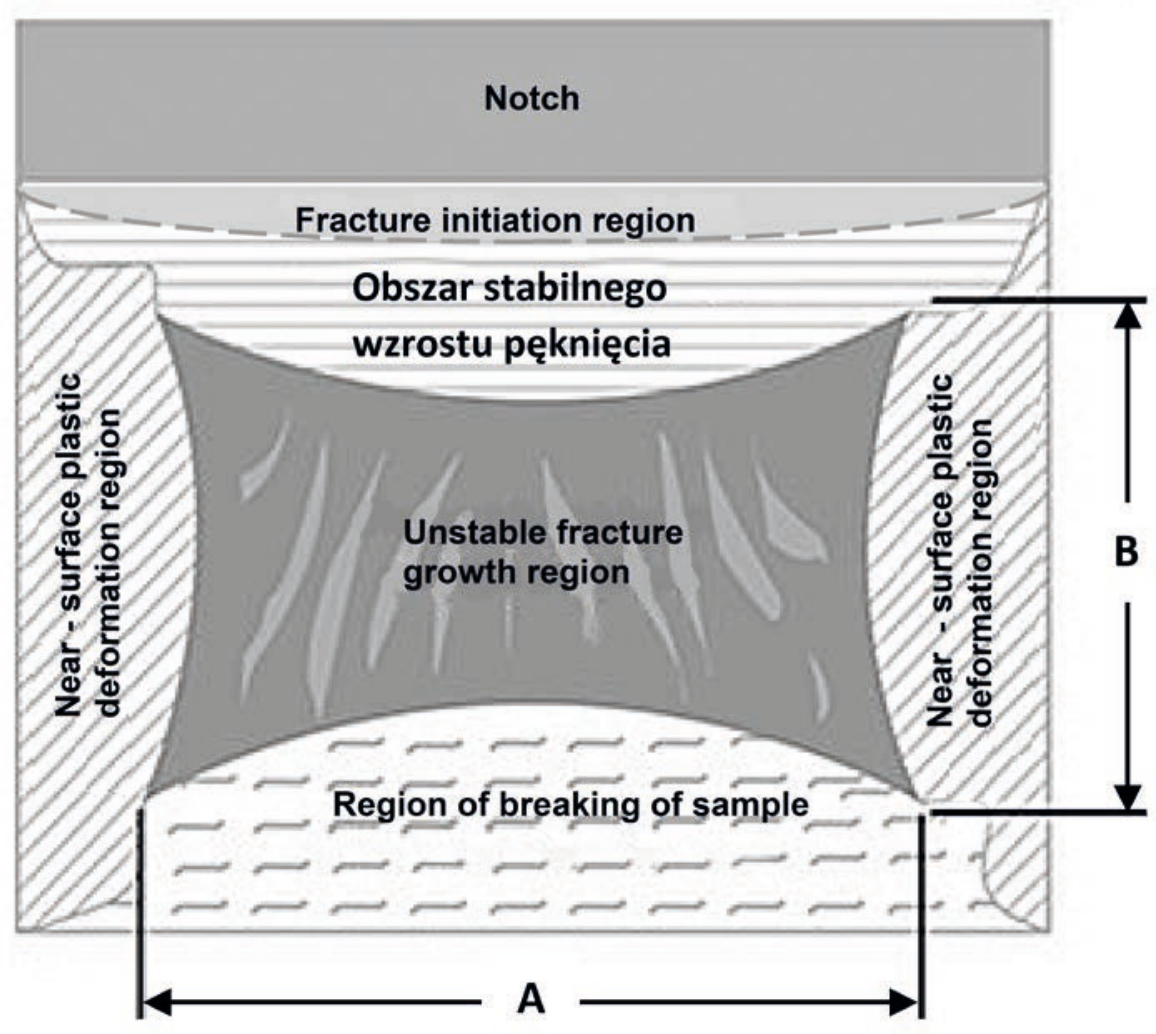


cracking enables the identification of those microstructure features that limit the material's resistance to crack growth (Knott, 1992).

The difference between the effects of inclusions is that the thermal expansion coefficients of inclusions, such as oxides and silicates, are smaller than the expansion coefficient of the crystallographic matrix, so the matrix "clamps" the inclusion. For example, manganese sulphides have a higher coefficient of thermal expansion than the matrix, so the inclusion shrinks in the matrix and creates a "void". Oxides and silicates are good initiators of brittle cracks because the continuity between the dislocation mesh in the matrix and the brittle particle is ensured, while manganese sulphides are initiators of voids that initiate plastic cracking.

Brittle fracture in most metals occurs through the nucleation of microcracks, assisted by a local plastic deformation of the surrounding material. Its further spread occurs when the local concentrated tensile stress exceeds a certain critical value. The grain size determines the length of the dislocation accumulation and the distance to the next grain extremity, which is a barrier to crack elongation. The process of brittle cracking in steels involves the following three stages: nucleation of cracks at particles of, for example, carbide; propagation of cracks at the carbide-ferrite interface; propagation of cracks at the first ferrite-ferrite grain boundary. The dominance conditions of each stage vary depending on microstructure and temperature. According to literature (Lin, Evans and Ritchie, 1987), the nucleation of cracks at carbide particles requires plastic deformation of the ferrite. In experimental studies (Curry and Knott, 1978), (Lin, Evans and Ritchie, 1986), (Rosenfield, Shetty and Skidmore, 1983) it has been shown that there are broken carbide particles in the plastic zone near the crack.

If the particle size is very small, the crack stops at the interface. In that, its further propagation is impossible. However, particles containing stable cracks can be further sources of void growth when plastic cracking occurs. Rapidly propagating cracks undergo unstable growth with little plasticity. The first carbide particle in which crack nucleation and propagation outside the ferrite extremity occurs is the basis for a critical crack.

At low temperatures, the dominant stage of cracking is crack nucleation at the carbide particles. At higher temperatures, when the carbide particle resistance to crack exceeds its yield point, as well as the strength of the matrix grain, but is smaller than the peak stress, the particles crack without causing failure. Particles meeting the dynamic propagation criterion: particle - crystallographic matrix

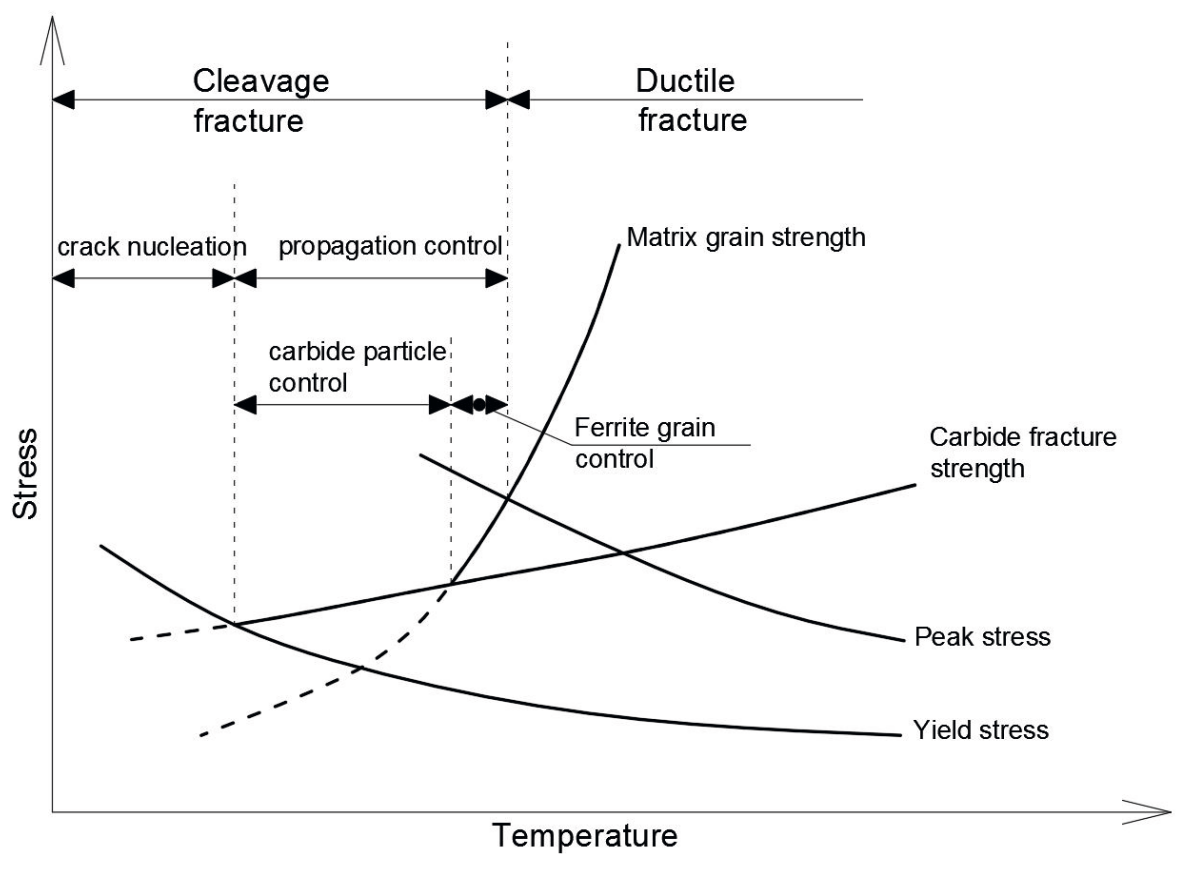

Temperature become a source of brittle cracking. At even higher temperatures, when the carbide fracture strength and matrix grain strength exceed its yield point, but at the same time the matrix strength exceeds the carbide fracture strength, the particles may crack and the fracture stops at the first phase interface. At the highest temperature, when the peak stress is smaller than the carbide fracture strength and the matrix grain strength, the transition to plastic fracturing occurs. However, particle cracking may still occur above the transition temperature. There are stable cracks, but they can act as ovules of voids that cause plastic fracturing (Lin, Evans and Ritchie, 1987).

Fig. 5. Crack nucleation control regions by propagation (Lin, Evans and Ritchie, 1987) 
Plastic fracture is created by separation processes limited by two mechanisms: void coalescence and fast shearing. The progress of the crack in the case of joining voids corresponds to the mechanism occurring in a situation of the regular distribution of non-coherent inclusions. Tensile stress in the material causes blunting of the crack end and displacement of its front by the dislocation movement, initiating the formation of a void. Due to the acting tensile stress, the void expands until it joins the crack end. The mechanism of fast shearing cracking is the creation of voids around the inclusions, and when the microcrack initiation occurs, the merging of voids occurs in the shear band connecting the tip of the crack with the nearest initiated void. Rapid destruction occurs when the deformation in the shear band reaches a critical level and fails to inhibit the microcrack in carbide or other brittle particle. In the case of a plastic fracture, it is important that in the absence of inclusions initiating voids that allow shear destruction, crack growth is only possible when the loading increases.

There are two forms of brittleness in intergranular fractures. One of these concerns cracks caused by hydrogen transported to the voids initiated by inclusions. The crack spreads in deformed areas and brittle fracturing occurs at its tip. The second form of brittleness is formed by the segregation of sulphur at a temperature of about $500^{\circ} \mathrm{C}$ to the grain extremities in the area of maximum triaxial stress before the notch. The extremity becomes brittle and the crack gradually propagates by joining the initial notch tip (Knott, 1992).

The mechanism for arresting brittle cracks is different from the mechanism of initiation. The crack arrest occurs when the local motive load at the crack end decreases below local arresting resistance on a sufficiently large part of the crack front. A single local crack arrest does not imply arresting the entire crack front because the spread depends on the average and not on the local matrix properties. In literature (Wallin at al., 2002), it was demonstrated that the temperature dependence on crack arrest resistance is the same as in the case of resistance to brittle fracture initiation. This makes it possible to link the crack arrest resistance with the Charpy test.

In terms of transition temperature, two mechanisms of cracking competehigh temperature cracking and low temperature intergranular cracking. Plastic cracking increase the volume before the crack end and increases towards weakened places in the structure. However, brittle cracking is controlled by the occurrence of brittle inclusions in the zone before the crack tip (Haušild at al., 2002).

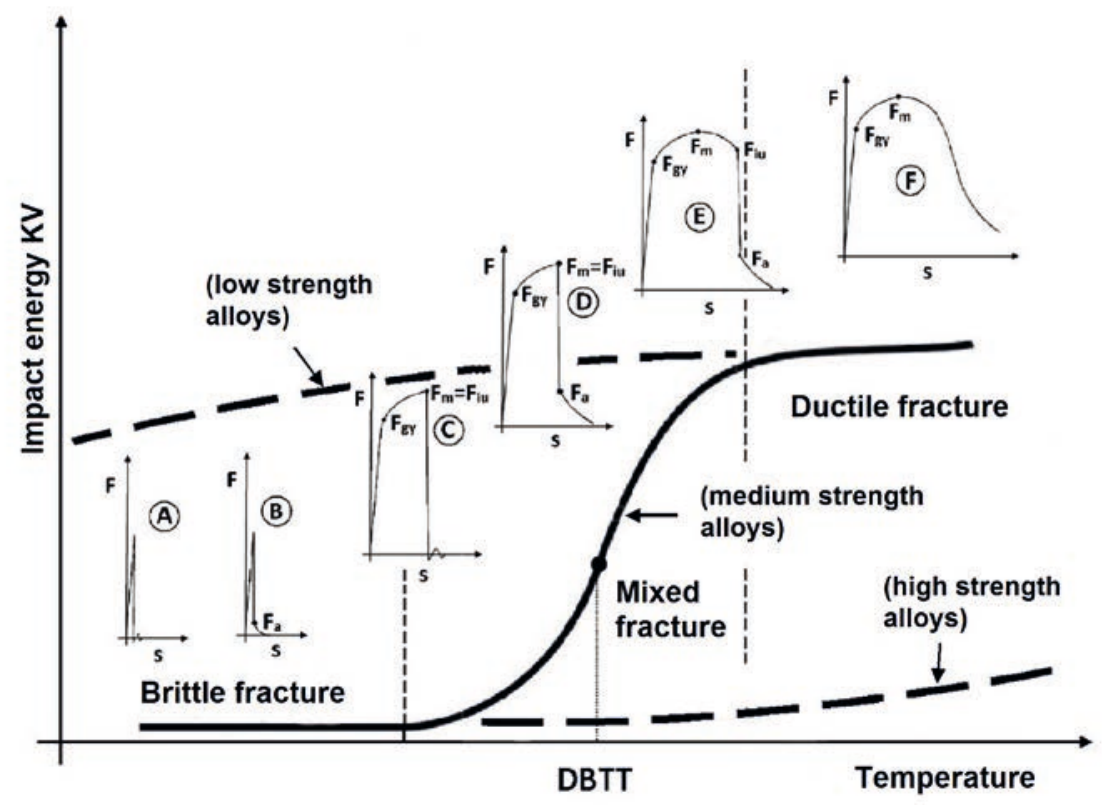

Fig. 6. Assignment of characteristic F-s graphs from the Charpy impact test to areas of the steel transition curve [own study according to (PN-EN ISO 14556:2015)] 


\section{Conclusions}

The Instrumented Charpy impact test of fire-exposed steels is a way to assess the effect of changes on the deformability that occurs in its microstructure during exposure to fire. The mechanism of steel destruction determines the safety of people working on extinguishing a fire and cleaning up the area after a fire. The changes in the microstructure described in this paper are often the reason for the increase in the hardness of the material, with a simultaneous deterioration of plastic properties and a radical decrease in impact strength. Such transformations result in an increased risk of brittle cracking (Canale, Mesquita and Totten, 2008), causing a sudden loss of load capacity and a catastrophic destruction.

The planned tests will be the first of a series of impact tests. They will be extended in the future by other simulated fire models and how to extinguish them. The purpose of these studies is to predict how the material may behave during chaotic heat treatment, to what extent it will be degraded and what the risk is of changing the mechanism of cracking from plastic to brittle.

Load-displacement curves obtained from the instrumented Charpy impact test should correspond to the F or E standard types. In case of the type E graph, the characteristic points of the graph should fulfil dependencies described in the $C$ attachment of the standard (PN-EN ISO 14556:2015), ensuring a plastic fracture level of no less than $70 \%$ to $90 \%$. When testing thick-walled elements that are more prone to brittle cracking in comparison to thin-walled elements, the index of plastic fracture should be taken at $90 \%$ or alternatively, the impact test temperature should be lowered, as required by the standard.

The paper has discussed the impact of microstructure on the nature of the crack brittle or plastic) and presents the mechanisms of these fractures. Adjusting the load-displacement curve to the steel transition curve makes it possible to draw unambiguous conclusions about the material's ability for continued use after a fire. In the author's opinion, the instrumented Charpy impact test enables a sufficiently precise and explicit assessment of steel structural elements after a fire in terms of brittleness risk. 


\section{References}

Bednarek, Z., Kamocka, R. (2006). The heating rate impact on parameters characteristic of steel behaviour under fire conditions, Journal of Civil Engineering and Management, XII/ 4, 269-275.

Canale, L.C.F., Mesquita, R.A., Totten, G.E. (2008). Failure Analysis of Heat Treated Steel Components, ASM International Materials Park, Ohio.

Chaouadi, R., Fabry, A. (2002). On the utilization of the instrumented Charpy impact test for characterizing the flow and fracture behavior of reactor pressure vessel steels. In D. François, A. Pineau (Eds.) From Charpy to present impact testing (pp. 103-117), Elsevier Science Ltd. and ESIS.

Curry, D., Knott, J.F. (1978). Effect of microstructure on cleavage fracture stress in steel, Metal Science, 12, 511-514.

Haušild, P., Bompard, P., Berdin, C., Prioul, C., Karlik, M. (2002). Influence of ductile tearing on cleavage triggering in ductile-to-brittle transition of A508 steel. In D. François, A. Pineau (Eds.) From Charpy to present impact testing (pp. 79-86), Elsevier Science Ltd. and ESIS.

Knott, J.F. (1992). Micromechanisms of fracture - the role of microstructure. In S. Sedmak, A. Sedmak, D. Ruzic (Eds.) ECF9 Reliability and Structural Integrity of Advances Materials, (pp. 1375-1400), Varna, Bulgaria.

Lin, T., Evans, A.G., Ritchie, R.O. (1986). Statistical analysis of cleavage fracture ahead of sharp cracks and rounded notches, Acta Metallurgica, 34, 2205-2216.

Lin, T., Evans, A.G., Ritchie, R.O. (1987). Stochastic Modeling of the Independent Roles of Particle Size and Grain Size in Transgranular Cleavage Fracture, Metallurgical Transactions A, 18A, 641-651.

Lin, Y., Yang, W., Tong, Z., Zhang, C., Ning G. (2017). Charpy impact test on A5083 steel after neutron irradiation, Engineering Failure Analysis, 82, 733-740.

Maciejewski, K., Sun, Y., Gregory, O., Ghonem, H. (2012). Time - dependent of low carbon steel at elevated temperatures, Materials Science and Engineering $A, 534,147-156$.

Maślak, M. (2012). Badania stali konstrukcyjnej po pożarze w kontekście oceny możliwości jej dalszego użytkowania w elementach nośnych ustrojów budowlanych, Przegląd Budowlany, 6, 48-51.

Maślak, M., Żwirski, G. (2017). Changes in structural steel microstructures following and cooling episodes in fires, Safety \& Fire Technique, 48, 34-52.

Peng, P.C., Chi, J.H., Cheng, J.W. (2016). A study on behavior of steel structures subjected to fire using non-destructive testing, Construction and Building Materials, 128, 170-175.

PN-EN ISO 14556:2015: Metale. Próba udarności sposobem Charpy’ego z karbem V. Oprzyrządowana metoda badania.

Rosenfield, A.R., Shetty, D.K., Skidmore, A.J. (1983). Fractographic observation of cleavage initiation in the ductile-brittle transition region of a reactorpressure-vessel steel, Metallurgical Transactions A, 14 A, 1934-1937.

Server, W.L. (2002). Instrumented Charpy Test review and application to structural integrity, In D. François, A. Pineau (Eds.) From Charpy to present impact testing (pp. 205-212), Elsevier Science Ltd. and ESIS.

Sorochak, A.P., Maruschak, P.O., Yasniy, O.P., Vuherer, T., Panin, S.V. (2017). Evaluation of dynamic fracture toughness parameters of locomotive axle steel by instrumented Charpy impact test, Fatigue \& Fracture of Engineering Materials \& Structures, 40, 512-522.

Stankiewicz, M., Holloway, G., Marshall, A., Zhang, Z., Ślązak, B. (2012). Próba udarności Charpy'ego i parametr Lateral Expansion w ocenie materiatów spawalniczych dla potrzeb kriogeniki, Przegląd Spawalnictwa, 11, 1-7.

Tanguy, B., Besson, J., Piques, R., Pineau, A. (2005). Ductile to brittle transition of an A508 steel characterized by Charpy impact test. Part II: modeling of the Charpy transition curve, Engineering Fracture Mechanics, 72, 413-434. 
Trilleros, J.A., Mato, S., Huertas, I. (2012). Development of a pilot furnace for testing structural steels under standard fire model. In S.L. Chan, G.P. Shu (Eds.) Proceedings of 7th International Conference: Advances in Steel Structures (pp. 821-830), Nanjing.

Wallin, K., Nevasmaa, P., Planman, T., Valo, M. (2002). Evolution of the Charpy-V test from a quality control test to a materials evaluation tool for structural integrity assessment. In D. François, A. Pineau (Eds.) From Charpy to present impact testing (pp. 57-68), Elsevier Science Ltd. and ESIS. 


\title{
Ocena przydatności wybranych gatunków stali konstrukcyjnej do użytkowania po pożarze \\ na podstawie wyników zinstrumentalizowanej próby udarności
}

\begin{abstract}
Streszczenie
W artykule omówiono zmiany zachodzące w stali konstrukcyjnej po chaotycznej obróbce termicznej, jaką jest pożar. Struktura stali przed i po pożarze determinuje jej podatność na kruche pękanie. Poszczególne fazy pękania zostały opisane i zinterpretowane na podstawie wykresu sita-przemieszczenie, uzyskanego bezpośrednio z badania udarności oprzyrządowanym młotem Charpy'ego. Wykazano zależność pomiędzy wielkością poszczególnych energii pęknięcia a rodzajem i wyglądem przełomu próbki. Zaprezentowano program planowanych badań udarności za pomocą oprzyrządowanego mtota Charpy'ego oraz spodziewane zagrożenia występujące po pożarowej obróbce termicznej w wybranych gatunkach stali. Typowe, normowe uproszczone wykresy sita - przemieszczenie przyporządkowano do krzywej przejścia stali w stan kruchy. Omówiono przy tym przebieg różnych mechanizmów pękania, zachodzących w przypadku przełomu kruchego i alternatywnie, przełomu plastycznego. Celem artykutu jest potwierdzenie możliwości miarodajnej oceny stali konstrukcyjnej po pożarze na podstawie wyników uzyskanych podczas próby udarności oprzyrządowanym mtotem Charpy’ego.
\end{abstract}

Słowa kluczowe: próba udarności oprzyrządowanym młotem Charpy’ego, przełom kruchy, przetom plastyczny, przetom mieszany 